\title{
Assessment of Power Compeers Prospective of Gobecho Micro Hydropower Plant on Ganga River, Genale Dawa River Basin, Ethiopia
}

\author{
Abebe Temesgen Ayalew \\ Faculty of Hydraulic and Water Resources Engineering, Water Technology Institute, Arbaminch, Ethiopia \\ Email address: \\ teabeman@gmail.com \\ To cite this article: \\ Abebe Temesgen Ayalew. Assessment of Power Compeers Prospective of Gobecho Micro Hydropower Plant on Ganga River, Genale Dawa \\ River Basin, Ethiopia. American Journal of Electrical Power and Energy Systems. Vol. 10, No. 2, 2021, pp. 25-31. \\ doi: $10.11648 /$ j.epes. 20211002.12
}

Received: February 5, 2021; Accepted: March 24, 2021; Published: April 26, 2021

\begin{abstract}
Micro hydropower helps the rural areas to supply power with off grid electrification. This study deals with the design of micro hydropower scheme in Gobecho kebele, Genale Dawa river basin, Ethiopia. The site for the construction of diversion weir is located upstream of the Ganga river in the kebele. The design were implemented based on the available hydrological data collected from 1991 to 2020 river discharge at different stations by selecting the one, which is near to the Gobecho catchment. Ererti is a station geographically near to Gobecho catchment by using GIS 10.7 application. The Gobecho peak probable discharge of $3.503 \mathrm{~m}^{3} / \mathrm{s}$ is computed using log normal distribution after L-moment analysis. Based on this peak discharge, vertical drop weir and components of headwork structure designed and provided relevant dimensions. The proposed vertical drop weir has a height of $0.703 \mathrm{~m}$, crest length $10 \mathrm{~m}$ and the design flow for a hydropower scheme is $0.132 \mathrm{~m}^{3} / \mathrm{s}$ estimated by FDC. The water passes through trapezoidal power canal of a $0.35 \mathrm{~m}$ width and a 0.43 height to a forebay tank. A forebay of size $9 \times 1.3 \times 1.7$ is provided at the end of the power canal. Moreover, the water leads from forebay to a $0.24 \mathrm{~m}$ diameter of penstock running one unit turbine and capacity of $25 \mathrm{kw}$. The selected type of turbine for proposed plant is cross flow turbine. Finally, the quantity of calculated estimate cost is 50,000 USD and the B/C ratio of 1.48 provided for this micro hydropower project.
\end{abstract}

Keywords: Discharge Estimation, L Moment, Flood Frequency, Micro Hydropower, Ganga River

\section{Introduction}

In Ethiopia, the electricity generation from water came to existence in the beginning of 1930s, when Aba Samuel hydropower scheme which was commissioned in 1932. This station is capable of generating 6MW of electricity [1]. According to Ministry of Mines and Energy, in 1990 the total energy requirement in Ethiopia was estimated 177.6Twh per year, out of which $76.1 \%$ from wood, $16.1 \%$ from agricultural by product, $5.3 \%$ from fuel oil, $1.1 \%$ from electricity, $0.8 \%$ from charcoal, and $0.6 \%$ from other energy sources [2, 3]. Ethiopia has got substantial hydropower potential estimated as $45,000 \mathrm{MW}$, out of this, less than $10 \%$ has been utilized and the remaining should be developed at small to large scale so that the source of energy for various uses can be replaced by this more environmentally friendly, highly efficient and perpetual alternative energy source [10]. When the micro hydropower plant that develops on Ganga River implemented, it will play its own role in solving the electric scarcity problem in rural areas of Bona zuria woreda and Gobecho kebele even though it does not have any contribution to the national grid.

\section{Materials and Methods}

\subsection{Description of the Study}

The proposed micro hydropower project is located on Ganga River that found in Sidama zone Gobecho kebele. Geographically, it is located between $6^{\circ} 35^{\prime} 29^{\prime \prime}$ to $6^{\circ} 42^{\prime} 48^{\prime \prime} \mathrm{N}$ latitude and $38^{\circ} 36^{\prime} 20^{\prime \prime}$ to $38^{\circ} 41^{\prime} 05^{\prime \prime} \mathrm{E}$ longitude. The Gobecho River catchment situates in Southern Region of Ethiopia, near Bona zuria town. It is about $491 \mathrm{~km}$ away from 
Addis Ababa and about $125 \mathrm{~km}$ from the capital of southern region that of Hawassa. This micro hydropower site situated in the Genale dawa basin see the delineation below.

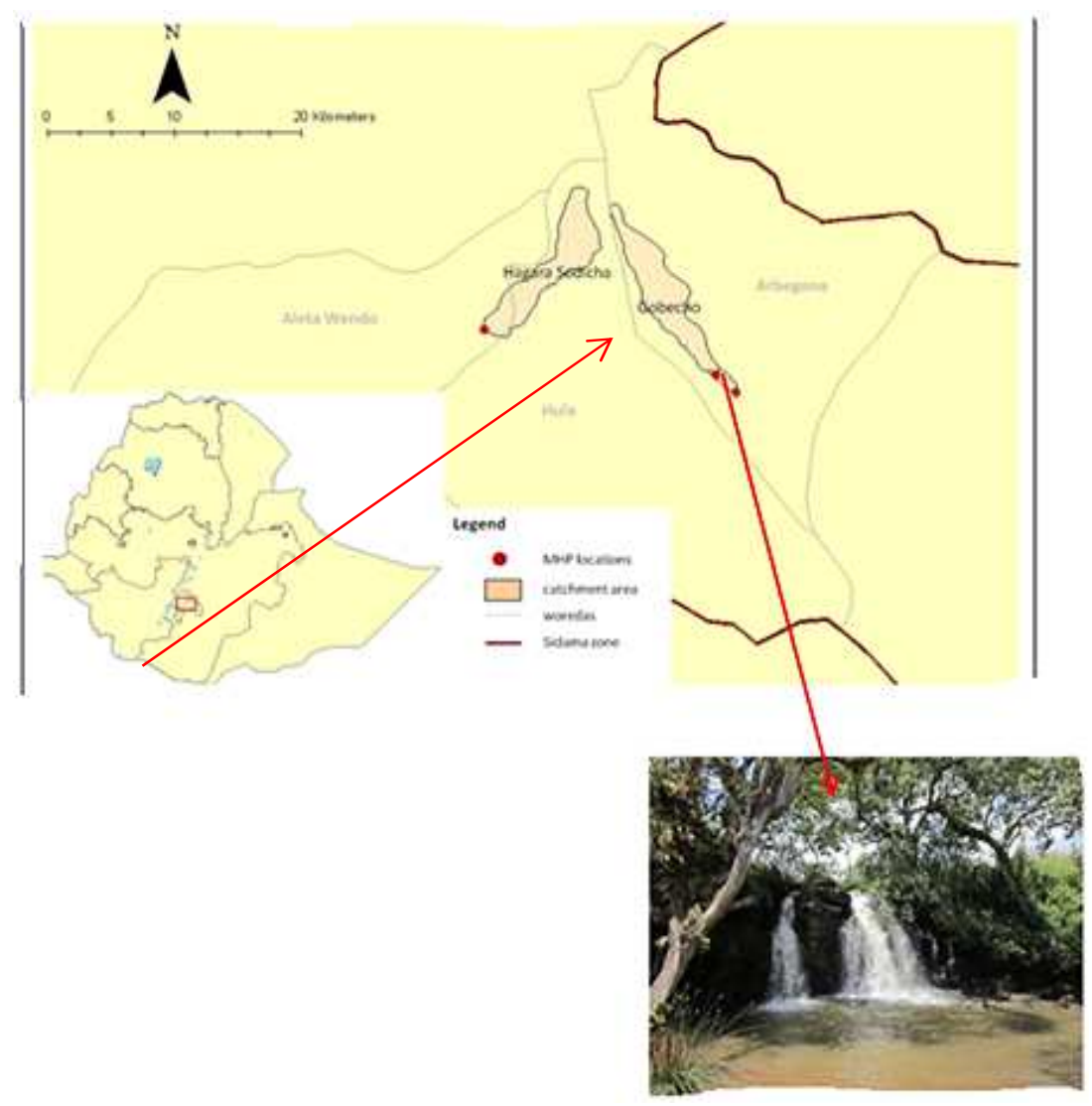

Figure 1. Location of Ganga river Waterfall and Gobecho I micro hydropower plant.

\subsection{Filling Missing Data}

Data with year or month missed because of different reasons. Some of these are failure of instrument, carelessness of the observer etc. In this project, graphical correlation used to obtain missing mean flow, maximum flow and minimum flow value $[2,9]$. We have selected this method due to the following reasons: - It is the most widely used method when compared to other Method. It has applied by creating a correlation with the given run-off and select best $r$ value with in power, exponential, linear etc. And the correlation coefficient, $\mathrm{r}$ in all cases is in between 0.6 and 1 .

\subsection{Transferring of Stream Flow Data}

The hydrological data of different stations are given in the original data. After filling the missing data, we try to find the station, which is near to the weir site (gobecho) from GIS 9.3 application we use the data of ererti that is geographically near to the weir site. Then from [4] and [8] $(A u /) \mathrm{b} * \mathrm{Qg} \mathrm{AU}$ $=54 \mathrm{~km}^{2}, \mathrm{Ag}=58.9 \mathrm{~km}^{2}$ Since the ratio of $\boldsymbol{A} \boldsymbol{u} / \boldsymbol{A} \boldsymbol{g}=0.9168$ is $b / n 0.8$ to 1 then use $b=1$.

\subsection{Consistency of Stream Flow}

Before using stream flow data, it should be check for consistency [6]. And 30 years of flow data is used from 1991-2020. If the conditions relevant to the recording of gauge station have undergone a significant change during the period of record, inconsistency would arise.

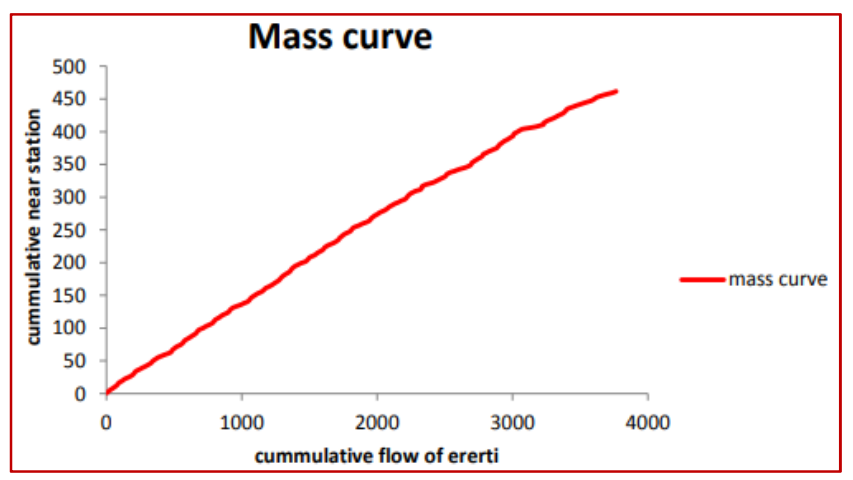

Figure 2. Double mass curves for station Ererti.

\subsection{Flow Duration Curve}

Flow duration curves are plot using the average monthly values of the flow. Depending on the flow duration curve, the conventional discharge values tabulated as follows:-

Table 1. Convectional discharge.

\begin{tabular}{ll}
\hline Convectional discharge & Value from FDC $\left(\mathrm{m}^{3} / \mathbf{s e c}\right)$ \\
\hline Q100 & 0.067 \\
Q95 & 0.132 \\
Q50 & 0.624 \\
\hline
\end{tabular}




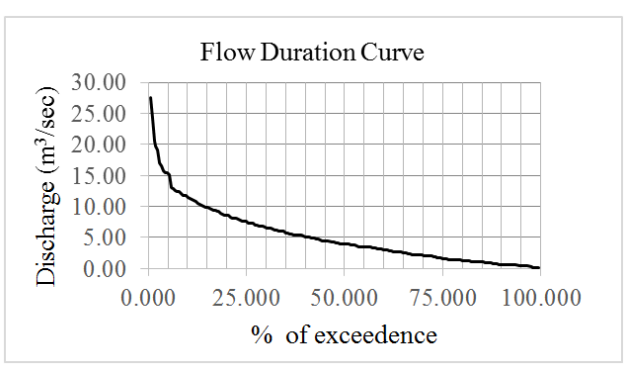

Figure 3. Flow duration curve.

\subsection{Potential Power Available at the Selected Site}

The actual use of the above equation however is made difficult because the discharge of any river various over the wide range of the year $[11,12,14]$. We adopt the $95 \%$ of the time available discharge. In the case of Hydropower plant without storage reservoir (i.e. in this case diversion canal plants) technically available power calculated by taking the overall efficiency as 55 to $85 \%$. Therefore, $\mathrm{P}=\mathrm{g} \rho \eta \mathrm{QHgross}$ $\mathrm{P}=0.55$ to $0.85^{*}$ (gQHgross). The head available to generate power $=$ the gross head is estimated as $25 \mathrm{~m}$ (from topography map after contour generation) $\mathrm{P}=0.77 * 9.81 * 0.132 * 25=25 \mathrm{kw}$

\begin{tabular}{|c|c|c|c|c|c|c|c|}
\hline Year & Q avg & Qpeak & $\eta$ & $\mathrm{H}_{\text {net }} / \mathrm{m} /$ & $\mathrm{g} / \mathrm{m}^{3} / \mathrm{s} /$ & $\begin{array}{c}\mathrm{P}(\mathrm{KW}) \\
\text { Avg }\end{array}$ & $\begin{array}{c}\mathrm{P}(\mathrm{KW}) \\
\text { Peak }\end{array}$ \\
\hline 1991 & 1.15 & 1.59 & 0.77 & 25 & 9.81 & 218 & 301 \\
\hline 1992 & 1.36 & 1.99 & 0.77 & 25 & 9.81 & 256 & 376 \\
\hline 1993 & 1.4 & 2.12 & 0.77 & 25 & 9.81 & 265 & 400 \\
\hline 1994 & 1.43 & 2.27 & 0.77 & 25 & 9.81 & 269 & 429 \\
\hline 1995 & 1.15 & 1.99 & 0.77 & 25 & 9.81 & 217 & 376 \\
\hline 1996 & 1.26 & 1.63 & 0.77 & 25 & 9.81 & 239 & 307 \\
\hline 1997 & 0.44 & 0.88 & 0.77 & 25 & 9.81 & 82.3 & 166 \\
\hline 1998 & 0.51 & 0.86 & 0.77 & 25 & 9.81 & 96.5 & 163 \\
\hline 1999 & 0.45 & 0.9 & 0.77 & 25 & 9.81 & 84.2 & 162 \\
\hline 2000 & 0.48 & 1.09 & 0.77 & 25 & 9.81 & 90 & 206 \\
\hline 2001 & 0.91 & 1.98 & 0.77 & 25 & 9.81 & 172 & 374 \\
\hline 2002 & 0.77 & 1.55 & 0.77 & 25 & 9.81 & 145 & 292 \\
\hline 2003 & 0.87 & 1.97 & 0.77 & 25 & 9.81 & 164 & 372 \\
\hline 2004 & 0.49 & 0.79 & 0.77 & 25 & 9.81 & 92 & 151 \\
\hline 2005 & 0.59 & 1 & 0.77 & 25 & 9.81 & 110 & 189 \\
\hline 2006 & 0.47 & 0.8 & 0.77 & 25 & 9.81 & 89 & 151 \\
\hline 2007 & 0.49 & 0.97 & 0.77 & 25 & 9.81 & 92.4 & 182 \\
\hline 2008 & 0.38 & 0.93 & 0.77 & 25 & 9.81 & 90.8 & 175 \\
\hline 2009 & 0.48 & 0.95 & 0.77 & 25 & 9.81 & 156 & 280 \\
\hline 2010 & 0.83 & 1.49 & 0.77 & 25 & 9.81 & 110 & 293 \\
\hline 2011 & 0.58 & 1.55 & 0.77 & 25 & 9.81 & 143 & 275 \\
\hline 2012 & 0.76 & 1.46 & 0.77 & 25 & 9.81 & 72.8 & 119 \\
\hline 2013 & 0.39 & 0.63 & 0.77 & 25 & 9.81 & 84.2 & 195 \\
\hline 2014 & 0.45 & 1.03 & 0.77 & 25 & 9.81 & 124 & 254 \\
\hline 2015 & 0.66 & 1.35 & 0.77 & 25 & 9.81 & 124 & 217 \\
\hline 2016 & 0.66 & 1.15 & 0.77 & 25 & 9.81 & 147 & 288 \\
\hline 2017 & 0.78 & 1.52 & 0.77 & 25 & 9.81 & 585 & 288 \\
\hline 2018 & 3.1 & 5.03 & 0.77 & 25 & 9.81 & 585 & 949 \\
\hline 2019 & 0.95 & 2.36 & 0.77 & 25 & 9.81 & 178 & 446 \\
\hline 2020 & 1.25 & 2.62 & 0.77 & 25 & 9.81 & 236 & 495 \\
\hline
\end{tabular}

Figure 4. Yearly flow data record.

\subsection{Flood Frequency Analysis}

The frequency analysis in hydrology is a statistical method used to show that events of certain magnitudes may on average expected once every $\mathrm{N}$ year. There are different methods of flood frequency analysis. The most commonly known methods [5] expressed as follows

1. Normal Distribution Method

2. Gumbel Distribution Method

3. Log Pearson type III Distribution Method

4. General Extreme Value Distribution

5. Log normal Distribution

6. Uniform Distribution

7. Exponential Distribution

8. Normal Distribution

\subsection{Method of Moments}

Sample estimator of L-moment are linear combinations of the ranked observation and thus do not involve squaring or cubing the observations. That is why it said L moments. In a wide range of hydrological applications, L-moments provide simple and reasonably efficient estimator of the characteristics of hydrologic data and distribution parameters [6].

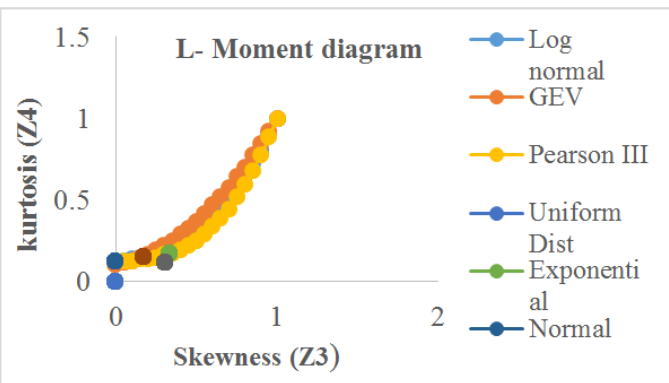

Figure 5. L-moment chart from the skewness versus kurtosis plot, the distribution that best fit to our weir site is Log normal distribution.

Log normal distribution

In this method, the flow values in the record converted to the logarithmic form of base ten. In this distribution, logarithmic values of sample data assumed to follow normal distribution. The distribution is same as log Pearson type-3 when $\mathrm{Cs}=0$.

\section{Design of Micro Hydropower Components}

\subsection{Design of Weir Required}

\subsubsection{Input for the Design}

From frequency analysis $\mathrm{Q}=3.503 \mathrm{~m}^{3} / \mathrm{s}$ is from $\mathrm{P}=$ $4.75^{*} \mathrm{Q}^{\wedge} 0.5=4.75^{*} 3.75^{\wedge} 0.5=8.890$ and add $20 \%$ allowance to get effective waterway length (Le). Hence, $\mathrm{Le}=8.89 * 1.2=10.6 \mathrm{~m}$, adopt $\mathrm{Le}=10 \mathrm{~m} . \mathrm{Cd}=2.2$ by assuming the max value of $\mathrm{Cd}, \mathrm{Q}=\mathrm{Cd}^{*} \mathrm{Le}^{*} \mathrm{He}^{\wedge} 3 / 2$, rearrange the equation and solve for $\mathrm{He}$, Then $\mathrm{He}=0.281$ firstly assume 
$\mathrm{He}=$ hd for the calculation of head of the weir. Then $\mathrm{P} / \mathrm{Hd}$ versus $\mathrm{Cd}$ from table below it is possible to find the ratio $\mathrm{P} / \mathrm{Hd}=2.5$. Then easily $\mathrm{P}=\mathrm{Hd} * 2.5$ finally we get $\mathrm{P}=0.703$ $\mathrm{m}$, free board allowance 4 to $5 \%$ of $\mathrm{p}$, approach velocity $\mathrm{Va}=$ $0.486 \mathrm{~m} / \mathrm{s}$, corresponding velocity head $=0.012 \mathrm{~m} / \mathrm{s}$. After this it is possible to find $\mathrm{Hd}=\mathrm{He}-\mathrm{Ha}=0.281-0.012=0.296$.

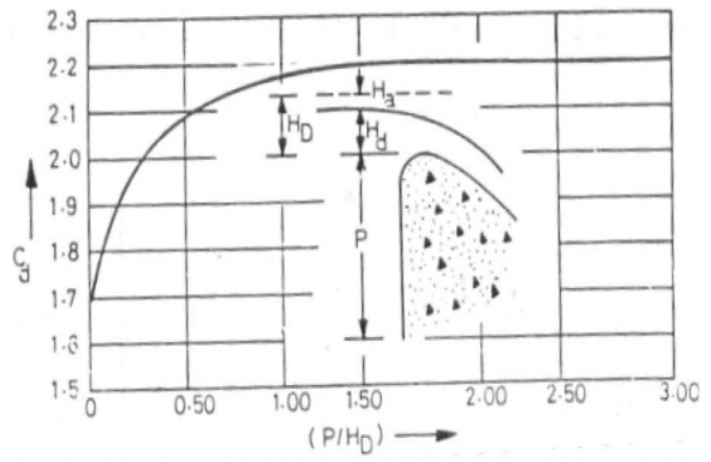

Figure 6. Plot of coefficient of discharge, Cd versus P/HD. [1].

From $\mathrm{Cd}$ versus HD plot of the above figure, various textbooks give in the form of a table just as provide shown below.

Table 2. Determination of weir height according to Cd

\begin{tabular}{llllll}
\hline P/Hd & Cd & P/Hd & Cd & P/Hd & Cd \\
\hline 0 & 1.7 & 0.1 & 1.875 & 0.2 & 1.97 \\
0.3 & 2.025 & 0.4 & 2.06 & 0.5 & 2.09 \\
0.6 & 2.12 & 0.7 & 2.135 & 0.8 & 2.15 \\
0.9 & 2.16 & 1 & 2.17 & 1.5 & 2.185 \\
2 & 2.195 & 2.5 & 2.2 & 3 & 2.205 \\
\hline
\end{tabular}

Table 3. D/s and $u /$ s profile of weir

\begin{tabular}{llll}
\hline \multicolumn{2}{l}{ Upstream profile } & \multicolumn{2}{l}{ Downstream profile } \\
\hline $\mathbf{X}$ & $\mathbf{Y}$ & $\mathbf{X}$ & $\mathbf{Y}$ \\
\hline 0 & 0 & -0.01 & 0.003 \\
0.1 & 0.022 & -0.02 & 0.004 \\
0.2 & 0.078 & -0.03 & 0.006 \\
0.3 & 0.165 & -0.04 & 0.008 \\
0.38 & 0.255 & -0.05 & 0.012 \\
& & -0.06 & 0.018 \\
& & -0.073 & 0.034 \\
\hline
\end{tabular}

Table 4. Stability analysis of ogee weir.

\begin{tabular}{|c|c|c|c|c|c|c|c|c|}
\hline \multirow[b]{2}{*}{ S. No } & \multirow[b]{2}{*}{ Load } & \multirow{2}{*}{$\begin{array}{l}\text { Load } \\
\text { Designation }\end{array}$} & \multicolumn{2}{|c|}{ Magnitude of force } & \multicolumn{2}{|c|}{ Moment arm } & \multicolumn{2}{|c|}{ Moment KNm/m } \\
\hline & & & Vertical & Horizontal & $\uparrow \downarrow$ & $\begin{array}{l}\rightarrow \\
\leftarrow\end{array}$ & $\mathbf{M}+\mathbf{V e}$ & M-Ve \\
\hline 1 & Water load & PWh1 & & 3.515 & & & & 0.82 \\
\hline \multirow[t]{5}{*}{2} & & W1 & 0.041 & & 0.74 & & 0.031 & \\
\hline & & W2 & 1.2 & & 0.75 & & 0.9 & \\
\hline & Self-weight & W3 & 1.6 & & 0.57 & & 0.923 & \\
\hline & & W4 & 4.265 & & 0.53 & & 2.26 & \\
\hline & & W5 & 1.9 & & 0.22 & & 0.43 & \\
\hline \multirow[t]{2}{*}{3} & Uplift force & PU & 2.812 & & & 0.53 & & 1.5 \\
\hline & Sum & & 6.2 & 3.515 & & & 2.32 & \\
\hline
\end{tabular}

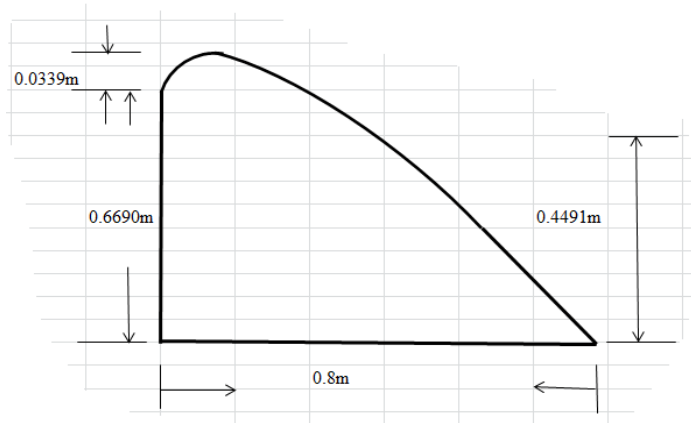

Figure 7. Design profile of ogee weir.

\subsubsection{Check for Stability Analysis of Weir}

\section{A. Factor of safety against overturning}

$\Sigma \mathrm{M}+\mathrm{Ve}=4.374 \mathrm{KNm} / \mathrm{m}, \quad \Sigma \mathrm{M}-\mathrm{Ve}=3.37 \mathrm{KNm} / \mathrm{m} \quad \mathrm{F}_{\mathrm{O}}=$ $\Sigma \mathrm{M}+\mathrm{Ve} / \Sigma \mathrm{M}-\mathrm{Ve}=4.54 / 2.32=2.0>1.5$, so it is safe against overturning. Sliding stability $\mathrm{F}_{\mathrm{SS}}=\Sigma \mathrm{H} / \Sigma \mathrm{V}=3.515 / 6.2=$ $0.567<0.75$ so it is safe against sliding.

B. Factor of safety against shear and tension

Over stress From table above $\Sigma \mathrm{M}=\Sigma \mathrm{M}+\mathrm{Ve}-\Sigma \mathrm{M}-\mathrm{Ve}=4.54-$ $2.32=2.22, \Sigma \mathrm{V}=6.2, \mathrm{c}=\Sigma \mathrm{M} / \Sigma \mathrm{V}=2.22 / 6.2=0.358$, width of weir $\mathrm{T}=0.8 \mathrm{~m} \mathrm{e}=\mathrm{T} / 2-\mathrm{c}=0.042, \mathrm{~T} / 6=0.133$. Then, $\mathrm{e}<\mathrm{T} / 6$ no tension is developed. Max stress $\delta \max =\Sigma \mathrm{V} / \mathrm{T}\left(1+6{ }^{*} \mathrm{e} / \mathrm{T}\right)$ $=10.19 \mathrm{KN} / \mathrm{m}^{2}$. Hence, the maximum stress is not much large which is safe against incoming stress.

\subsubsection{Design of Impervious Floor}

According to Bligh's theory, the percolating water flow the outline of the base of the foundation of the hydraulic structures. It assumed in this theory, that the loss of head is proportional to the length of the creep. For design of hydraulic structure like wears on previous foundation, Khosla's has evolved a simple, quick and an accurate approach [8].

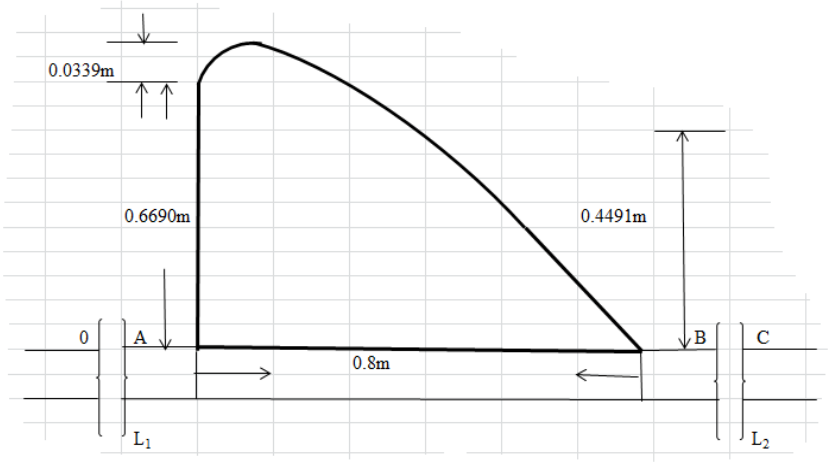

Figure 8. Dimension of Impervious floor of weir. 


\subsection{Intake Design}

For small-scale hydropower, it is better to select roughly finished masonry orifice type of intake with allowable velocity ranges $1-1.5 \mathrm{~m} / \mathrm{s}$ (small-scale hydropower lecture note). Hence, we assume $\mathrm{V}=1.2 \mathrm{~m} / \mathrm{s}$ and from our previous calculation $\mathrm{Qd}=$ $0.132 \mathrm{~m}^{3} / \mathrm{s}$. Area, $\mathrm{A}=\mathrm{Q} / \mathrm{V}=0.132 / 1.2=0.11 \mathrm{~m}^{2}$ Assume orifice intake height, $\mathrm{H}=0.2$ and we calculate the width. $\mathrm{W}=\mathrm{A} / \mathrm{H}=0.11 \mathrm{~m}^{2} / 0.2 \mathrm{~m}=0.55 \mathrm{~m}$ Therefore, the size of the intake $=0.55^{*} 0.2$. Check the flow through the orifice using submerged orifice equation. Qsub $=A^{*} C^{*} \sqrt{2} g$ (Where for roughly finished masonry $\mathrm{C}=0.6$, hh is the depth of water in the headrace canal $=0.28$ (for normal flow condition) $\mathrm{hr}=$ height of normal water level in the river $\mathrm{u} / \mathrm{s}$ of the weir=hweir+ hovertop For normal flow condition hovertop $=0$ then $\mathrm{hr}=0.703+0=0.703 \mathrm{~m}$. Qsub $=\mathrm{A} * \mathrm{Cd} * \sqrt{2} g=0.19 \mathrm{~m}^{3} / \mathrm{s}>0.132 \mathrm{~m}^{3} / \mathrm{s}$, it is submerged. Therefore, our assumption is correct.

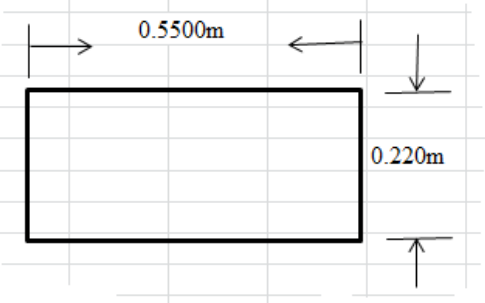

Figure 9. Intake Design.

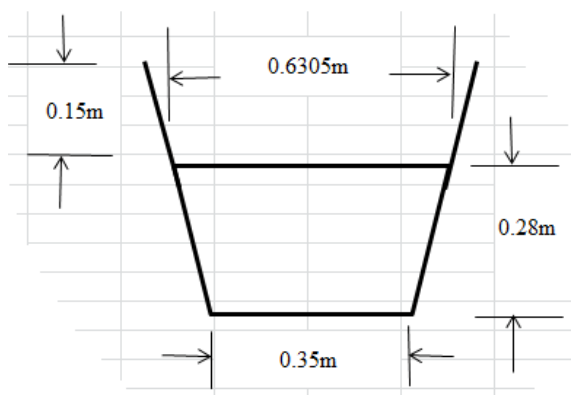

Figure 10. Design of head race canal.

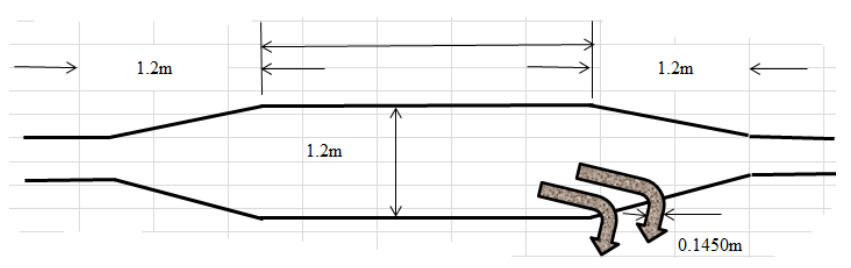

Figure 11. Design of Settling Basin.

Design of Forebay

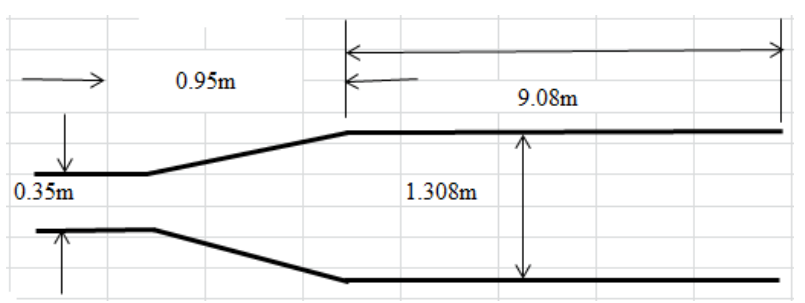

Figure 12. Design of forebay.
Design of Spillway for the Forebay

Table 5. Design of spillway for forebay.

\begin{tabular}{llllll}
\hline $\mathrm{X}(\mathrm{m})$ & 0 & 0.05 & 0.1 & 0.15 & 0.184 \\
$\mathrm{Y}(\mathrm{m})$ & 0 & 0.011 & 0.04 & 0.085 & 0.085 \\
\hline
\end{tabular}

\subsection{Design of Penstock}

In hydropower scheme, the cost of penstock is very high and if the number of penstock is many, the total weight of steel required and construction cost is expensive [4, 15, 19]. On the other hand, large diameter, for a given discharge, will result small head loss and greater available net head. As the diameter increases the velocity decreases and the capital investment will get higher, therefore a size, which gives least cost selected.

$\mathrm{D}=0.176(\mathrm{P} / \mathrm{H}) \quad 0.466=0.243$ From above calculations adopt, $\mathrm{D}=0.24 \mathrm{~m}$ Therefore, we take diameter of penstock $=$ $0.24 \mathrm{~m} \&$ velocity in penstock $=3.5 \mathrm{~m} / \mathrm{s}$.

\subsubsection{Thickness of Penstock}

The appropriate wall thickness for a penstock is generally a function of penstock material selected that is steel tensile strength, the diameter of the penstock and the operating pressure it will experience during its use [7, 20].

For weld and assuming thin cylinder thickness $\mathrm{t}=\mathrm{P} D / 2$, hw $=C V \quad g \quad \mathrm{C}=\sqrt{\mathrm{k}} / \mathrm{p}$

Where P- total pressure t- Thickness of penstock Vovelocity in the penstock C-celerity wave velocity of water $\mathrm{K}$ Bulk modulus of water $(2.18 * 109 \mathrm{KN} / \mathrm{m} 3) \rho$ - Density of water $(1000 \mathrm{KN} / \mathrm{m} 3)$ D- inside diameter of penstock $\mathrm{P}=$ (Static pressure +water hammer pressure) g $\mathrm{P}=(25+526.8)$ $\times 9.81=5413.158 \mathrm{KN} / \mathrm{m} \mathrm{t}>\mathrm{P} D / 2 \boldsymbol{\rho} \boldsymbol{\eta} a \geq 0.00465=4.6 \mathrm{~mm}$ $\Leftrightarrow \mathrm{D} / \mathrm{t}=240 / 4.6=52>20 \mathrm{Ok}$ !

\subsubsection{Selection of Turbine}

The applicable range of each type of turbine according to $[16,17,18]$.By using net head of $25 \mathrm{~m}$, required power of $25 \mathrm{kw}$ and discharge of $0.132 \mathrm{~m}^{3} / \mathrm{s}$. For this value of head and discharge cross flow turbine was selected from Figure 12.

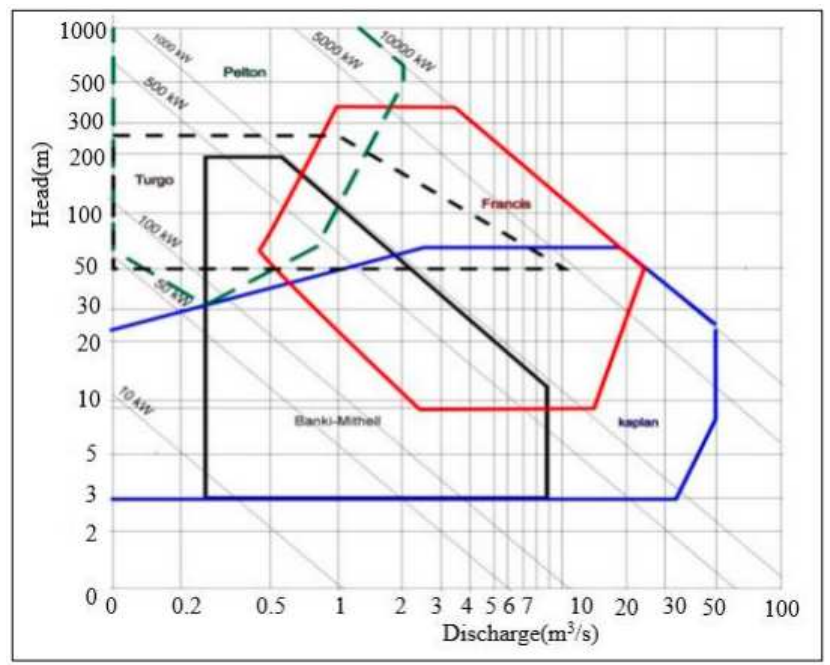

Figure 12. Turbine selection chart [21] 


\subsubsection{Specific Speed and Rotational Speed}

$\mathrm{Ns}=(\mathrm{N} \sqrt{ } \mathrm{P}) / \mathrm{H}^{5 / 4}$ Where: $\mathrm{NS}=$ specific speed $\mathrm{N}=$ rotational speed $(\mathrm{rpm}) \mathrm{P}=$ power developed $(\mathrm{kW})=\rho \mathrm{ghQH}$ $=9.81 * 0.77 * 0.132 * 25=25 \mathrm{KW}$ Turbine efficiency, $=77 \%$ for cross flow turbine (JICA, Department of Energy 2003) H = effective head $(\mathrm{m})$ The exact value of rotational speed $(\mathrm{N})$ for cross flow (T12, T-13, T-14) can be calculated as follows:- N $=133 \sqrt{ } \mathrm{H}=133 \sqrt{2}=665 \mathrm{rpm}((\mathrm{JICA}$, Department of Energy 2003) $\mathrm{Ns}==(\mathrm{N} \sqrt{\mathrm{P}}) / \mathrm{H}^{5 / 4}=665 * \sqrt{2} / 251.25=59.5=60 \mathrm{rpm}$ Number of poles, $\mathrm{P}=50 * \mathrm{f} / \mathrm{N}=4.5$ Where $\mathrm{f}=$ frequency, $50 \mathrm{HZ}$ for Ethiopia For heads up to 200 the numbers of poles is multiple of is four, take number of poles 8 . We can also select the type of turbine based on the specific speed, Ns

1. Francis turbine $60 \leqq \mathrm{Ns} \leqq 300$

2. Cross flow turbine $40 \leqq \mathrm{Ns} \leqq 200$

3. Propeller turbine $250 \leqq \mathrm{Ns} \leqq 1000$

From the above ranges, we select cross flow turbine. Cross flow, turbines have the following advantage in micro hydropower.

1. Simple for construction

2. It is locally manufactured and cheap

3. Easy for maintenance

\subsubsection{Number of Units Installed}

Normally, it is most cost effective to have a minimum no of units at a given installation.

$$
\begin{aligned}
& \mathrm{N}=\mathrm{N} S * H^{5 / 4} / \sqrt{\mathrm{P}}=\left(\left(\mathrm{Ns}^{*} \mathrm{H}^{\wedge} 5 / 4\right) / \mathrm{N}\right)^{2}=\mathrm{P} \text { then } \mathrm{P}=25.4 \\
& \text { No of unit }=\mathrm{p} / \mathrm{p} 1=25.4 / 25=1 \text { unit }
\end{aligned}
$$

\subsubsection{Powerhouse Dimension}

The length of the machine hall depends on the number of units and the size of machine. Using the standard layout set by [10] between $c / c$ of two units is- $\mathrm{L}=[(4.5$ to 5$) \times D+(2-$ $3 \mathrm{~m}$ ) for minimum clearance] +minimum one unit erection bay $\mathrm{L}=(4.5 \times 0.1+2.5)+1=4 \mathrm{~m}$

Width: The width of machine hall is determined by the size and the clearance from the halls needed as gantry way $[9,10]$.

$$
\text { Width }=2 \mathrm{Lr}+2.52 * 0.10+2.5=2.7 \mathrm{~m}
$$

Height: - The height of the machine hall fixed by the headroom requirement. The hall must have a height that will enable the crane to lift the rotor of the generator or the runner of the turbine clear of the floor without any abstraction. For this project, height lets taken to be $3 \mathrm{~m}$

\subsection{Design of Tailrace Channel}

It is the portion of the power canal, which extends from the powerhouse to the recipient watercourse. Adopting most economical rectangular section $\mathrm{A}=2 \mathrm{Y}^{2} \mathrm{~A}=Q \quad V$ Where: $\mathrm{A}=$ area of the channel $\mathrm{Q}=$ Discharge that converged from the turbine $=0.132 \mathrm{~m} / \mathrm{s}$ V $=$ Velocity of flow $=2 \mathrm{~m} / \mathrm{s} Y=$ Channel depth

$\mathrm{A}=0.132 / 2=0.066 \mathrm{~m}^{2} \quad \mathrm{Y}=\sqrt{ } \mathrm{A} / \mathrm{Z}, \mathrm{Y}=(0.066 / 2)^{\wedge} 0.5=$ 0.1816 Adding free board $=0.1 \mathrm{~m}, \mathrm{Y}=0.2816 \mathrm{~m} \mathrm{~A}=\mathrm{b}^{*} \mathrm{Y}$ $\mathrm{b}=\mathrm{A} / \mathrm{Y}=0.066 / 0.1816=24 \mathrm{~m}$, Applying Manning's' equation: $V=1 / n R^{2 / 3} S^{1 / 2}$ For concrete lining $n=0.016$ for most economical section $\mathrm{R}=\mathrm{Y}=0.2816=48 \mathrm{~m}^{2}$ So $\mathrm{n}=0.016$ for economical cross section. $\mathrm{R}=\mathrm{Y} / 2=002816 / 2=48 \mathrm{~m}^{2}$. Therefore, a tailrace channel having $0.2816 \mathrm{~m}$ depth, $0.234 \mathrm{~m}$ width assumed length up to $3 \mathrm{~m}$ and $1 / 71$ bed slope.

\section{Conclusion}

The Gobecho micro hydropower project is low capacity low head plant due to the availability of the low head and low power production. Since the main purpose of the project is fulfilling the light scarcity in the Gobecho kebele in addition to considering the downstream ecology. That is why providing small discharge with low capacity to drive the generator accompanied by turbine rotation. The discharge provided in the hydrological data results in the provision of ogee weir height $0.703 \mathrm{~m}$ in order to regulate the flow for maximum possible power production. Regarding the conveyance of the structure of masonry trapezoidal canal provided to minimize the cost that consumed due to usage of full concrete canal instead it is able to implement by locally available stones and a penstock of length $70 \mathrm{~m}$ is suited to convey water under pressure to the turbine after removing from the fore bay. From the result of economic and financial analysis, the total cost estimated to be 50,000 USD with a benefit cost ratio of 1.48 and thus the project is economically feasible. Generally, taking all these points in to consideration the implementation of the project is feasible and crucial in order to satisfy a sustainable electric energy demand for the country.

\section{Statement on Conflicts of Interest}

There is no conflict of interest.

\section{References}

[1] Abbasi, T., Abbasi, S. A. (2011). Small Hydro and the Environmental Implications Of Its Extensive Utilization. In: Renewable and Sustainable Energy Reviews, 15, P. 21342143.

[2] Agricultural Water Management Information System of Ethiopia (Awmiset) (Ed.) (2009): River Basins of Ethiopia. Http://Www.Mowr.Gov.Et/Awmiset/Pages/Map1.Html (13.06.2011)

[3] Baldenhofer, K. (2002): Bodenverdichtung. In: Brunotte, E. Et Al. (Ed.) (2002): Lexikon Der Geographie. Vol. 1. Heidelberg, Berlin: Spektrum. P. 195.

[4] Beltrando, G., Camberlin, P. (1993): Interannual Variability Of Rainfall In The Eastern Horn Of Africa And Indicators Of Atmospheric Circulation. In: International Journal Of Climatology, 13, P. 533-546.

[5] Beyene, M.G., Herzig, S. (2011): Ethiopia Wind Profile (Unpublished Fact Sheet Produced By Wind Energy Ppp Project Office).

[6] Bölli, M., Feibel, H.(2008): Baseline Study: Access To Modern Energy Services In Ethiopia (Ames-E) (Unpublished, Specifically Produced For Giz). 
[7] Ethiopian Central Statistical Agency First edition (Ed.) (2007): Population and Housing Census of Ethiopia 2007.http://Www.Csa.Gov.Et/Pdf/Atlas\%20cencus\%202007.P df (06.06.2011)

[8] Central Statistics Authority (Ed.) (1996): The 1994 Population and Housing Census Of Ethiopia Results For Southern Nation And Nationalities People Region. Vol I: Part I Statistical Report On Population Size and Characteristics. Addis Ababa: Central Statistics Authority.

[9] Convention on Biological Diversity (Ed.) (2011). (Undated): Country Profile of developing countries prospective base in Ethiopia. http://Www.Cbd.Int/Countries/Profile.Shtml?Country=Et\#Stat us

[10] Cernea, M. M. (2004): Social Impacts and Social Risks In Hydropower Programs: Preemptive Planning and CounterRisk Measures. (Keynote Address: Session On Social Aspects Of Hydropower Development, United Nations Symposium On Hydropower And Sustainable Development Beijing, China, 27-29.

[11] B. C. Kusre, D. C. Baruah, P. K. Bordoloi, and S. C. Patra, (2010). "Assessment of hydropower potential using GIS and hydrological modeling technique in Kopili River basin in Assam (India)," Applied Energy, vol. 87, no. 1, pp. 298-309.

[12] M. Teferra, (2002). "Power sector reforms in Ethiopia: options for promoting local investments in rural electrification," Energy Policy, vol. 30, no. 11-12, pp. 967-975.

[13] J. K. Kaldellis, D. S. Vlachou, and G. Korbakis, (2005). "Techno-economic evaluation of small hydro power plants in Greece: a complete sensitivity analysis," Energy Policy, vol. 33, no. 15 , pp. 1969-1985.
[14] G. A. Aggidis, E. Luchinskaya, R. Rothschild, and D. C. (2010). Howard, "The costs of small-scale hydro power production: impact on the development of existing potential," Renewable Energy, vol. 35, no. 12, pp. 2632-2638.

[15] J. L. Gordon and A. C. Penman, (1979). "Quick estimating techniques for small hydro potential," Journal of Water Power and Dam Construction, vol. 31, pp. 46-55.

[16] A. Date and A. Akbarzadeh, (2009) "Design and cost analysis of low head simple reaction hydro turbine for remote area power supply," Renewable Energy, vol. 34, no. 2, pp. 409415 .

[17] U. G. Wali, (2013). "Estimating hydropower potential of ungauged stream," International Journal of Emerging Technology and Advanced Engineering, vol. 3, no. 11, pp. 592-600.

[18] C. S. Kaunda, C. Z. Kimambo, and T. K. Nielsen, (2012). "Potential of small-scale hydropower for electricity generation in Sub-Saharan Africa," ISRN Renewable Energy, vol. 2012, Article ID 132606, 15 pages.

[19] M. Saikia, (2014). "Remote village electrification by small hydropower project in Assam," Indian Journal of Energy, vol. 3, no. 1 , pp. 140-147.

[20] D. Derbew, (2013). “Ethiopia's Renewable and clean Energy Power Potential assessment and Development program and creating Opportunities," http://www.irena.org/DocumentDownloads/events/July/Africa $\% 20$ CEC $\% 20$ session\%203 Ministry\%20of\%20Water\%20and $\% 20$ Energy\%20Ethiopia_Beyene_220613.pdf.

[21] Layman's, H. (1998). On how to develop a small hydro site. The British Journal of Psychiatry, 112(483), 211-212. https://doi.org/10.1192/bjp.112.483.211-a 